\title{
Institutional quality and the capital structure of microfinance institutions: the moderating role of board gender diversity
}

\author{
Michael Adusei* and Beatrice Sarpong-Danquah \\ Department of Accounting and Finance, Kwame Nkrumah University of Science and Technology, Kumasi, Ghana \\ *Corresponding author. Email: madusei.ksb@knust.edu.gh
}

(Received 7 September 2020; revised 24 December 2020; accepted 31 December 2020;

first published online 10 February 2021)

\begin{abstract}
We test the effect of institutional quality on capital structure in the microfinance setting. In doing this, we rely on data from 532 microfinance institutions (MFIs) located in 73 countries dotted across the six microfinance regions in the world. We observe that institutional quality exhibits a robust negative and statistically significant relationship with capital structure in both the short and long run, implying that MFIs in countries with a better institutional environment are less likely to utilize more debt. Our moderation analysis furnishes us with evidence that the presence of women on the board of an MFI significantly moderates the relationship between institutional quality and its capital structure. We show that in the presence of more female representation on the boards of MFIs, the tendency of MFIs using less debt is higher.
\end{abstract}

Key words: Capital structure; institutional quality; microfinance institutions; women on boards

JEL codes: G32; G37

\section{Introduction}

The finance literature recognizes that both firm-level features and institutional environment ${ }^{1}$ determine access to external funding sources (Demirgüç-Kunt and Maksimovic, 1999). The link between institutional quality and access to external funding sources is predicated on institutional theory, which argues, among other things, that norms, regulations, and social pressures external to a firm and outside the control of the firm influence its behaviors and outcomes (Selznick, 1957). The postulation is that the institutional environment within which firms operate carries isomorphic pressures such that firms embrace practices that are deemed legitimate and socially acceptable as well as align with those of similar firms in the environment (DiMaggio and Powell, 1983).

Studies that link institutional environment to capital structure argue that better institutional environment enhances firms' ability to access external funding on favorable terms (e.g. Awartani et al., 2016; Booth et al., 2001; Demirgüç-Kunt and Maksimovic, 1999; Fan et al., 2012; Garmaise and Natividad, 2010; Li and Ferreira, 2011). The central thesis espoused by these studies is that better institutions impact information frictions prevalent in credit markets resulting in some influence on the funding policies of firms. Many of these studies have employed data from publicly listed firms, keeping their primary focus on the effects of investor protection, financial sector development, and corruption on the capital structure decisions of these public firms (e.g. Awartani et al., 2016; Fan et al., 2012). To date, little is known about the impact of institutional settings on the financing decisions of privately

\footnotetext{
${ }^{1}$ In this paper, institutional environment, institutional settings and institutional quality are used interchangeably.

(c) The Author(s), 2021. Published by Cambridge University Press on behalf of Millennium Economics Ltd. This is an Open Access article, distributed under the terms of the Creative Commons Attribution licence (https://creativecommons.org/licenses/by/4.0/), which permits unrestricted re-use, distribution, and reproduction in any medium, provided the original work is properly cited.
} 
held firms such as microfinance institutions (MFIs). Exceptions include a few studies such as Demirgüç-Kunt et al. (2020), Namara et al. (2017), Daskalakis et al. (2017), Psillaki and Daskalakis (2009), and Beck et al. (2008) that provide some insights from small and medium scale enterprises (SMEs). We seek to contribute to the budding strand of literature on the institutional settings-capital structure nexus of privately held firms with data from the microfinance industry. We interrogate the question of whether institutional quality drives the capital structure of MFIs. We also address the question of whether board gender diversity plays any significant role in the institutional quality-capital structure linkage. As far as we know, the existing microfinance literature does not address these two important questions. Therefore, addressing them affords us the opportunity to shape policy.

MFIs have become an essential layer in the financial architecture of most economies, especially the developing ones. For them to perform their hybrid role of offering financial and non-financial services on favorable terms to their indigent clients and doing this in a financially sustainable way, a task sometimes referred to as the microfinance promise (Morduch, 1999), the issue of funding is crucial. This is because funding equips MFIs with the resources they need to improve their social performance and to pursue product and geographical diversification (Earne and Sherk, 2013). However, little empirical attention has been paid to this topic. Exceptions include Adusei and Obeng (2019); Dorfleitner et al. (2019); Dortfleitner et al. (2017); Tchakoute Tchuigoua, (2016); Tchakoute Tchuigoua (2014); Mersland and Urgeghe (2013); Ledgerwood and White (2006); and Fernando (2004). Among these studies, it is only Tchakoute Tchuigoua (2014) that sheds some light on the effect of institutional framework on the funding behavior of MFIs. However, its focus on only three institutional variables (the strength of legal rights, a country's legal tradition, and the size of the banking sector) gives room for further empirical interrogation. We extend the previous study by taking a more comprehensive approach to institutional environment measurement. To this end, we measure institutional quality by the public governance indicators produced by Kaufmann et al. (2010) which aggregate and normalize several existing country ratings along six institutional dimensions (political stability and absence of violence, control of corruption, the rule of law, regulatory quality, government effectiveness, and voice and accountability). Besides, and contrary to previous research, we examine whether board gender diversity $^{2}$ moderates the relationship between institutional quality and the capital structure of MFIs. Evidence exists that the board of directors of a firm has a significant effect on its capital structure (Alves et al., 2015; Kieschnick and Moussawi, 2018). The literature arguably portrays women as more risk-averse than men (Byrnes et al., 1999). Women directors have a higher risk aversion than their male counterparts and are known to be better monitors (Adams and Ferreira, 2009; Sila et al., 2016). Given the bankruptcy risk involved in capital structure decisions of firm, it is interesting to know whether the presence of female directors on the boards of MFIs moderates the relationship between institutional quality and the capital structure of such institutions.

We focus on the public governance measure of institutional quality because public governance determines the confidence of economic agents that their claims and property rights, including financial assets, are fortified against expropriation by both government and private parties. The rule of law takes precedence over any other rule in a well-governed country, and sovereign institutions are reliable and believed to move toward adequate protection of property rights and contract enforcement (Belkhir et al., 2016). In such an environment, lenders have better confidence that their capital will be retrieved, which incentivizes them to lend more.

This paper differs from Tchakoute Tchuigoua (2014) and extends the existing literature on the institutional quality-capital structure link in six distinct ways. First, Tchakoute Tchuigoua (2014) measures the institutional environment by the strength of creditor rights, a country's legal tradition, and the level of financial sector development. This study departs from this conceptualization by exploring whether six institutional variables (political stability and absence of violence, control of corruption, the rule of law, regulatory quality, government effectiveness, and voice and accountability) jointly and severally affect the capital structure of MFIs. Thus, the study provides some comprehensive

${ }^{2}$ In this paper, board gender diversity and women on boards are used interchangeably. 
insights into the institutional environment-capital structure nexus in the microfinance setting. We use the six public governance variables to construct an institutional quality index. Besides, we insulate the effect of each of the six governance variables on capital structure.

Second, this study deploys data from 532 MFIs distributed across the six MFI regions. This differs from 292 MFIs used by Tchakoute Tchuigoua (2014). Holding other factors constant, the use of a bigger sample size should offer a better insight into the effect of the institutional environment on the capital structure of MFIs.

Third, the microfinance industry continues to grow in leaps and bounds. For example, in 1997, the total client base of MFIs hovered around 10 million clients. However, by 2010 this number had skyrocketed to over 200 million (Reed, 2015). Besides, early 2010 marked a watershed in the microfinance history characterized by intensified commercialization culminating in over-indebtedness of some clients of MFIs as well as excessive profits of MFIs amid waves of criticisms of the industry (Microfinance Barometer, 2019). Thus, the use of data spanning 2010-2018 as against 2004-2009 data employed by Tchakoute Tchuigoua (2014) should offer some fresh insights into the funding decisions of MFIs in an era of increasing microfinance commercialization. Moreover, keeping our focus on 2010-2018 insulates our results from the influence of the 2007-2009 global financial crisis because the crisis years influenced the capital structure decisions of both listed and non-listed firms (Demirgüç-Kunt et al., 2020).

Fourth, evidence adduced in this paper suggests that the presence of women directors on the boards of MFIs moderates the negative effect of institutional quality on capital structure. This result is new to the existing literature. Thus, it distinguishes this paper from previous research.

Fifth, as far as we know, studies on the institutional framework-capital structure nexus in and outside the microfinance industry have not enlightened us on the short- and long-run effects of institutional environment on capital structure. We demonstrate that in both the short and long run, MFIs' debts are lower in countries where institutional quality is better. Thus, apart from our paper upholding pecking order theory as well as the managerial fear hypothesis, it also provides some illumination on the long-run effect of institutional environment on capital structure.

Finally, the determinants of the capital structure of privately held firms remain an important and unresolved issue in the finance literature (Cole, 2013). This is because previous research has overly concentrated on publicly held firms. Consequently, the findings of this study add to the few studies (Beck et al., 2008; Daskalakis et al., 2017; Demirgüç-Kunt et al., 2020; Namara et al., 2017; Psillaki and Daskalakis, 2009) that throw light on what influences the financing decisions of privately held firms.

The rest of the paper is organized as follows. In the next section, we review theories and relevant empirical studies. Next, we provide information on the materials and methods used. The penultimate section of the paper presents the results from the various estimations. The conclusion section follows.

\section{Literature review}

\subsection{Theoretical review}

We deploy three capital structure theories to predict the relationship between institutional quality and the capital structure of MFIs. Pecking order theory argues that due to costs (including information asymmetry costs), firms have a defined order of financing their operations. They begin with retained earnings (internal finance), followed by debt. The least preferred source of funding is equity (Donaldson, 1961; Frank and Goyal, 2009). Thus, holding other factors constant, firms that generate more earnings should use less debt in their capital structure.

The trade-off theory of capital structure (Myers, 1984) posits that the decision to utilize more debt in the capital structure of a firm is the trade-off between costs such as bankruptcy costs and the benefits (tax shield) of debt. Consequently, in an environment where the tax regime is favorable, and there are lower bankruptcy costs, more debt in the capital structure of firms should be expected, and vice versa. Recent evidence supports this postulation (Matemilola et al., 2019).

Similar to trade-off theory, agency theory (Jensen, 1986) postulates that there exists an optimal capital structure that beats down agency costs. Thus, holding other factors constant, better institutional 
quality that promotes transparency between providers of debt capital and firms should accelerate the use of more debt because the former will be willing to supply more debt capital.

In sum, whereas pecking order theory supports a negative relationship between institutional quality and capital structure, trade-off and agency theories endorse a positive relationship. We, however, expect a positive relationship. This is because a better institutional framework should boost the confidence of providers of debt capital to provide more capital, which should encourage MFIs to access more debt capital, resulting in higher leverage ratios.

\subsection{Empirical studies}

Outside the microfinance setting, many studies have demonstrated interest in untangling the connection between institutional factors and capital structure (Belkhir et al., 2016; Fan et al., 2012; Matemilola et al., 2019; öztekin and Flannery, 2012; Touil and Mamoghli, 2019). Matemilola et al. (2019) use 3,891 firms from 23 developing countries to examine the link between institutional quality and capital structure (debts). Their single aggregated index measure of institutional quality and disaggregated measures of institutional quality positively load on the capital structure (debt ratios) of firms both in terms of book and market values. They report similar results from their analysis of subsamples of 2,187 listed firms from seven Asian countries and 1,091 listed firms from six Latin American and Eastern European countries. However, the results from the subsample of 10 African countries reveal no significant effect of the aggregated measure of institutional quality on capital structure. Among the six disaggregated measures of institutional quality, the study finds only political stability and voice and accountability to be negatively and positively related to capital structure, respectively.

Belkhir et al. (2016) use data from 444 listed firms in 10 Middle East and North African (MENA) countries over the 2003-2011 period to investigate whether the firms have target leverage ratios to which they adjust over time. They report that the firms have target leverage ratios toward which they adjust over time. However, the speed of adjustment varies from one country to another. Apart from finding that firm-level factors influence leverage ratios, the study also finds that better institutional quality promotes the use of more debt. Awartani et al. (2016) deploy data from 444 firms in 10 MENA to examine the role of institutional quality in the choice between short-term and long-term debt utilization. Apart from the study reporting limited use of long-term debt in the MENA region, it also discovers that better quality institutions are associated with the use of more long-term debt in the area. The use of long-term borrowing is prevalent in MENA countries with stronger rule of law, better regulatory effectiveness, better legal protection of creditors, and more developed financial intermediaries (Awartani et al., 2016). In the same MENA region, Touil and Mamoghli (2019) employ data from 506 non-financial firms in 12 MENA countries listed on the stock exchange between 2006 and 2014 to investigate the role of institutions in the capital structure of firms. The study finds that whereas in the presence of good quality institutions the effects of firm profitability, non-debt tax savings and growth opportunities on capital structure are strengthened, the impact of firm size and returns volatility on capital structure are attenuated. Concerning speed of adjustment, although institutional quality reinforces the effect of profitability and distance from the target, the impact of firm return volatility, growth opportunities, non-debt tax savings, and asset tangibility on the adjustment process are moderated by the financial market development and the good quality of institutions.

Some studies have explored the issue of adjustment to target leverage ratios. Öztekin and Flannery (2012) employ a partial adjustment model to investigate whether institutional differences explain the variance in the estimated speeds of adjustment of firms in 37 developed and developing countries. They report that institutional factors explain adjustment speeds.

Fan et al. (2012) pick data from 39 developed and developing countries to assess the effect of institutional environment on capital structure and the debt maturity choices of firms. The study reports that firms in more corrupt countries and those with weaker laws tend to use more debt, especially short-term debt. Moreover, explicit bankruptcy codes and deposit insurance are associated with higher 
leverage and more long-term debt. Also, in countries where there is a higher tax gain from leverage, more debt is utilized.

Regarding the effect of institutional settings on the capital structure of non-listed firms, some studies have considered this linkage with data from SMEs. Namara et al. (2017) employ data from Europe to investigate the impact of countries' lending infrastructure (information, legal, judicial, bankruptcy, social, tax, and regulatory environments) on SMEs. Among other things, the study reports that the debt of SMEs is higher in countries with more efficient bankruptcy environments in terms of debt recovery as well as in countries with less stringent regulatory environments by way of lower capital regulatory requirements for banks. Demirgüç-Kunt et al. (2020) deploy a dataset covering about 276,998 firms across 75 countries over the period 2004-2011 to examine the effects of the global financial crisis on the capital structure of firms, including SMEs. The study reports that deleveraging and maturity reduction effects among SMEs were more substantial in countries with less efficient legal systems, weaker information-sharing mechanisms, less developed financial sectors, and with more restrictions on bank entry.

In the microfinance domain, studies on the capital structure of MFIs have looked at the effect of buffer capital on the financial performance of MFIs (Afrifa et al., 2019), board gender diversity effect on the capital structure of MFIs (Adusei and Obeng, 2019), drivers of buffer capital of MFIs (Tchakoute Tchuigoua, 2016), access of MFIs to debt capital from microfinance investment vehicles (Dortfleitner et al., 2017), how ratings influence the price of financing and assist MFIs in raising funds (Garmaise and Natividad, 2010), MFI funding practices (Ledgerwood and White, 2006; Fernando, 2004); access of MFIs to crowdfunding (Dorfleitner et al., 2019); and determinants of international funding of MFIs (Mersland and Urgeghe, 2013). As far as we know, the only study that explores the link between the capital structure of MFIs and their institutional environment is Tchakoute Tchuigoua (2014). Generally, the results from this paper show that the strength of creditor protection, legal origin, and financial sector development are significantly associated with the level of external finance. The positive and statistically significant link between financial sector development and borrowings leads the study to the conclusion that the microfinance sector and the formal banking sector are complementary.

The current study builds on the above literature by exploring the effect of institutional quality on the capital structure of 532 MFIs drawn from the six MFI regions in the world. In doing this, we deploy unbalanced data (2010-2018) from 532 MFIs in 73 countries.

\section{Materials and method}

\subsection{Empirical model and data description}

The following baseline dynamic model is specified and estimated by the two-step system generalized method of moments (GMM) estimator:

$$
Y_{i t}=c+\phi Y_{i t}-1+\gamma Z_{i t}^{\prime}+\beta X_{i t}^{\prime}+d_{t}+\varepsilon_{i t}
$$

where $Y_{i t}$ represents the measures of capital structure (the debt-to-equity ratio and the natural logarithm of MFI borrowings), $c$ is the intercept of the model, $Y_{i t-1}$ lagged dependent variable, $Z^{\prime}{ }_{i t}$ is the vector of control variables (profitability, size, and efficiency), $X_{i t}^{\prime}$ is the vector of explanatory variables (institutional quality index and its components as well as women on boards); $d_{t}$ represents time dummies; $\varepsilon_{i t}$ is the error term. $\phi, \gamma$, and $\beta$ are the coefficients to be estimated.

Credited to Arellano and Bover (1995) and Blundell and Bond (1998), the system GMM estimator uses moment conditions (instruments) that do not correlate with the regressors in the estimated model. We implement a collapse technique to avoid the proliferation of instruments. We rely on two statistics to test the reliability of results obtained from this estimator: Hansen statistic and Arellano-Bond autocorrelation test. The former checks the validity of the instruments used. The latter is used to test for serial correlation of the error term. 
The use of the GMM estimation technique provides some benefits. Apart from assisting us to address endogeneity concerns, GMM offers the unique opportunity to identify both the short-run as well as long-run effect of institutional quality on the capital structure of MFIs. As we do not know any previous inquiry that has addressed the question of long-run determinants of the capital structure of MFIs, this estimation approach endows us with the unique avenue to make a significant contribution to the capital structure literature.

We obtain the long-run coefficients of the variables in the above model by estimating the following equation:

$$
\text { Long-run coefficients }=\frac{\gamma_{i t}}{1-\lambda} \text { or } \frac{\beta_{i t}}{1-\lambda}
$$

where $\gamma$ represents the significant coefficients of the explanatory variables, and $\beta$ represents the significant coefficients of the control variables, $1-\lambda$ represents the rate of convergence.

We obtain MFI-level data from the Microfinance Information Exchange (http://www.mixmarket. org). It is a web-based platform that hosts data from thousands of MFIs across the six microfinance regions: Latin America and the Caribbean; South Asia; Eastern Europe and Central Asia; East Asia and the Pacific; Africa and MENA. This data source has been utilized by a growing number of studies in the field of microfinance (Adusei and Obeng, 2019; Ahlin et al., 2011; Tchakoute Tchuigoua, 2014). The main concern associated with MIX data is their self-reported nature. Data hosted by the platform are reported by the MFIs themselves, which raises the issue of reliability. However, MIX has introduced a quality control system over the last few years to ensure the validity of the data (Bibi et al., 2018). This quality control system involves the assignment of diamonds to the reporting MFIs, which range from 1 to 5 with a higher number of diamonds reflecting higher reliability of the reported data. We isolate only MFIs with four and five-diamond ratings for this study because of the superiority of their data to the other MFIs in the database. Financial statements of such MFIs are audited, with some of them audited by Big Four audit firms (Ahlin et al., 2011; Tchakoute Tchuigoua, 2014). The financial statements of five-diamond MFIs are rated by rating agencies (Tchakoute Tchuigoua, 2014).

A three-step filtering scheme has been applied to arrive at a sample of 532 MFIs located in 73 countries. First, for an MFI to be part of the sample, it must be rated either four or five diamonds. Next, the MFI must have some data covering the two measures of capital structure and the other MFI-level variables. The third step is that there must be some country-level (macroeconomic environment and institutional) data of the country in which the MFI operates. This requires that the data accessed from the MIX database be merged with the macro environment and institutional data. Given the dynamic model specified for the study, the third step in the data-filtering scheme requires that all MFIs not having at least 2-year data on the variables of interest should be excluded from the study. Using this sampling approach gives us unbalanced data from 532 MFIs with the distribution as follows: 37 banks, 70 credit union/cooperatives, 183 nonbank financial institutions (NBFIs), 224 nongovernmental organizations (NGOs), 9 rural banks, and 9 other MFIs. We provide the regional distribution of the sample in Appendix A. We obtain the macroeconomic and institutional data from World Bank statistics at http://www.worldbank.org, whereas data on institutional environments of MFIs are accessed from http://info.worldbank.org/governance/wgi/index.asp.

The application of the above filters limits the final sample to the 2010-2018 period. The use of this dataset offers two advantages. First, it shields our results from the effects of the 2007-2009 global financial crisis because the crisis years affected the capital structure decisions of both listed and nonlisted firms (Demirgüç-Kunt et al., 2020). Second, in early 2010, the microfinance industry witnessed a paradigm shift marked by intensified commercialization in the sector (Microfinance Barometer, 2019). It is, therefore, curious to investigate the effect of institutional quality on the capital structure decisions of MFIs during this period. 


\subsection{Measurement of variables and predicted relationships}

Given the fact that MFIs are mostly privately owned firms, it is not feasible to obtain market measures of their capital structure. We, thus, focus on the book value measures of their capital structure. Data constraints warrant the use of two measures of capital structure: the debt-to-equity ratio defined as total debt divided by total equity and borrowings defined as the natural logarithm of borrowings (nondeposit liabilities). However, the debt-to-equity ratio is our main measure of capital structure. These measures of MFIs' capital structure constitute our dependent variables.

The independent variables are the aggregate measure of institutional quality and its disaggregated measures made up of six public governance variables: political stability and absence of violence, control of corruption, the rule of law, regulatory quality, government effectiveness, and voice and accountability. The aggregate measure of institutional quality is defined as political stability and absence of violence + control of corruption + the rule of law + regulatory quality + government effectiveness + voice and accountability/6.

It is vital to predict the effect of each component of the institutional quality measure on the capital structure of MFIs. Political stability and absence of violence captures the perceptions of the probability of a government being toppled via violence means. Where there is a high perception of political stability, lenders of debt capital should not entertain any fear of supplying more debt capital. This points to a positive relationship between political stability and absence of violence and capital structure (Matemilola et al., 2019). On the contrary, lenders are reluctant to offer more debt in an unstable political climate (Matemilola et al., 2019). Notwithstanding the above, we expect a positive relationship between political stability and absence of violence and capital structure.

Defined as the misuse of state power by public officials for private gains (Shliefer and Vishny, 1993; Tanzi, 1998), corruption prevents public officials from facilitating contracts among private parties and enforcing property rights. This weakens the ability of investors to recover their investments, which ultimately undermines the development of financial markets (Chen, 2011; Du, 2008, Rose-Ackerman, 2006; and Stulz, 2005). Rising corruption in a country supports opportunistic tendencies of managers of firms in such countries because the ability of enforcement institutions to restrain managers from such tendencies is weak. Consequently, firms in countries marred by high corruption are likely to use debt instruments to control the opportunistic behavior of managers through restrictive debt covenants and other restrictions on a firm's free cash flow (Lemma, 2014). However, an alternative view exists that corruption could be a useful 'lubricant' against harsh economic regulation and red-tape (Belkhir et al., 2016). Notwithstanding the above, we project corruption to have a negative relationship with capital structure in this paper.

The rule of law indicator captures the extent to which agents operate within the confines of the law, the strength of property rights protection, and the degree of contract enforcement. In this regard, in countries where agents abide by the rule of law, property rights are protected, and contracts are enforced more effectively, firms are more likely to borrow more. This positive relationship between law and external finance is traced to La Porta et al. (1997) who find that smaller capital markets mark countries with weaker investor protection laws. However, contrasting views have since emerged. Studies that have taken the funds suppliers' view (supply-side factors) suggest that when the law offers sufficient protection to investors, they are confident to supply more funds (Djankov et al., 2007; Haselman et al., 2010). Thus, there is a positive relationship between law and external finance.

On the contrary, studies on the adverse effects of creditor rights on the borrowers' risk attitude (demand-side factors) have reported that stronger creditor rights are associated with lower leverage ratios of firms (Acharya et al., 2011; Cho et al., 2014; Shah et al., 2017; Vig, 2013). Embedded in these studies is the managerial fear hypothesis which states that stronger creditor rights instill the fear of bankruptcy in managers which finds its expression in either the manager employing a less-than-optimal level of leverage or holding unnecessarily high levels of cash to prevent costly winding up of their firms (Acharya et al., 2011; Cho et al., 2014; Vig, 2013). The higher risk-aversion of managers occasioned by improved creditor rights emanates from firm-specificity of human capital 
investment. Since human capital investment is firm-specific, the manager loses it to a large extent when their firm becomes extinct through bankruptcy. This drives managers to opt for lower leverage ratios (Amihud and Lev, 1981; Friend and Lang, 1988). Despite the above, we expect the rule of law to drive the capital structure of MFIs negatively.

Regulatory quality refers to the ability of a government to formulate and implement policies and regulations that foster a pleasant business climate and promote entrepreneurship, production, and exchange of goods and services. Belkhir et al. (2016) report that regulatory quality/effectiveness is positively associated with corporate leverage in MENA countries. Taking a cue from Belkhir et al. (2016), we expect regulatory quality to impact the capital structure of MFIs positively.

Government effectiveness is an index that captures perceptions of the quality of public services, the quality of the civil service and the degree of its independence from political pressures, the quality of policy formulation and implementation, and the credibility of the government's commitment to such policies. A higher index suggests effective governance and verse versa. An effective government should facilitate private business, which should enable MFIs to access credit on favorable terms, holding other factors constant. Thus, government effectiveness should be positively related to the capital structure of MFIs.

Voice and accountability captures the likelihood and the extent to which the citizens of a country are offered the opportunity to participate in the selection of their government. Holding other factors constant, where this index is high, lenders should be more confident to supply credit with a possible increase in the debt ratios of firms operating in that country. Matemilola et al. (2019) report that voice and accountability has a positive effect on debt ratios. Following Matemilola et al. (2019), voice and accountability should drive the capital structure of MFIs positively.

Another independent variable is board gender diversity. We measure women's representation on the boards of directors of MFIs by the number of female directors as well as the percent of women directors. Regarding the latter measure, we are not the first to use it. Studies such as Strom et al. (2014) and Adusei and Obeng (2019) have adopted a similar approach. Relying on the risk-averse theory of women (Byrnes et al., 1999), we expect a higher representation of women in the boardrooms of MFIs to be negatively related to capital structure.

We engage several control variables to ensure the reliability of our results. Profitability is proxied by the return on assets defined as net operating income-taxes divided by average assets. Based on the pecking order theory, profitability should be negatively related to the capital structure of MFIs because profit-making MFIs should finance their operations with retained earnings. Size as a control variable is measured by the natural logarithm of the total assets of an MFI. Notwithstanding the lack of clarity on the relationship between size and capital structure in the existing literature, we rely on the evidence of Matemilola et al. (2019), Oino and Ukaegbu (2015), and Frank and Goyal (2009) to predict a positive relationship. We account for an MFI efficiency in this study. It is measured by the natural logarithm of cost per borrower (US\$). An efficient MFI should generate sufficient profits to reduce reliance on external funding, especially debt. Efficiency is, thus, expected to have a positive relationship with capital structure.

Macroeconomic variables are known to affect the capital structure decisions of firms (Bancel and Mittoo, 2004; De Jong et al., 2008; Demirgüç-Kunt and Maksimovic, 1999; Fan et al., 2012; Namara et al., 2017; Tchakoute Tchuigoua, 2014). MFIs operate in complex socioeconomic situations. We address these complexities by introducing economic growth as a control variable measured by the annual real GDP growth rate. It is expected to positively drive the capital structure of MFIs since, all else being equal, an improvement in an economy should promote lending and borrowing. The existing literature documents that the degree of financial development of a country influences the financing decisions of firms operating in it (Adusei and Obeng, 2019; Beck et al., 2008; Tchakoute Tchuigoua, 2014). We measure financial development by the domestic credit provided by the banking sector as a share of GDP. The development of the banking sector is associated with a reduction in the costs of borrowing, which is likely to incentivize firms to raise more debt (Booth et al., 2001). Thus, financial development is expected to be positively associated with the capital structure of MFIs. 
Table 1. Descriptive statistics

\begin{tabular}{lccccc}
\hline Variable & Obs. & Mean & Std. Dev. & Min & Max \\
\hline Debt-to-equity ratio & 1,722 & 4.462 & 12.255 & -122.65 & 364.67 \\
\hline Borrowings (US\$) & 1,660 & $31,273,231.32$ & $89,054,489.61$ & 645 & $1,368,584,444$ \\
\hline Inst. quality & 1,641 & -0.47 & 0.39 & -1.742 & 1.197 \\
\hline Women on boards & 1,727 & 2.382 & 1.762 & 1 & 15 \\
\hline Growth & 1,641 & 3.376 & 2.746 & 18.695 & 16.017 \\
\hline Financial Dev. & 1,615 & 41.559 & 0.4 & 0.062 & 156.82 \\
\hline Profitability & 1,728 & 1.169 & 0.001 & 7.829 \\
\hline Size (US\$) & 1,736 & $87,328,924.06$ & $262,596,172.4$ & 9,042 & $34,44,417,025$ \\
\hline Efficiency (US\$) & 1,691 & 4.683 & 1.273 & 1.609 & 10.445 \\
\hline
\end{tabular}

\subsection{Summary statistics}

The summary statistics of the data are presented in Table 1 . The average debt-to-equity ratio is about 4.5. This suggests that MFIs are less geared. It may be because the MFIs in our sample depend more on subsidies than the use of commercial debt. It is documented that only $23 \%$ of the world's MFIs survive without subsidies (D'Espallier et al., 2013). The average institutional quality index of -0.47 suggests that the institutional quality of performance of the 73 MFI countries is low because the scale for each of the six public governance variables from which this index has been estimated is -2.5 to 2.5 with the higher value representing excellent performance.

The correlations between pairs of variables are presented in Table 2. Institutional quality exhibits some complex structure in that whereas it loads negatively on debt-to-equity ratio, its relationship with borrowings is positive although it is negligible. A quick inspection reveals that the correlations between pairs of independent and control variables are low. This supports the conclusion that multicollinearity may not bias our results.

\section{Empirical results}

\subsection{Baseline results}

The results ${ }^{3}$ from the baseline model are reported in Table 3. The diagnostics of the model are found in the table. Worthy of comment are the Hansen and AR (2) tests. The Hansen and AR (2) tests examine the validity of the instruments and the null hypothesis that there is no second-order serial correlation of the error term, respectively. The results of these tests reported in Table 3 suggest the validity of the results (Arellano and Bond, 1991; Arellano and Bover, 1995; Blundell and Bond, 1998). Columns 1 and 2 report the results when there are no control variables, whereas columns 3 and 4 report the results of the full baseline model. Across the four columns, the coefficient of institutional quality is negative and statistically significant. Under the debt-to-equity ratio measure of capital structure, a unit increase in the institutional quality index of a country causes between 1.587 and 1.863 drop in the capital structure of an MFI, holding other factors constant. These occur at the 5 and $1 \%$ significance levels, respectively. Under the borrowings measure of capital structure (columns 2 and 4), a unit change in the institutional quality of a country in which an MFI operates results in 26 and $68 \%$ drop in the capital structure of the MFI, holding other factors constant. This is observed at the 10 and 1\% significance levels, respectively. It implies that our prediction of a positive relationship is unsupported. Contradicting the study of Matemilola et al. (2019), our results appear to embrace pecking order

\footnotetext{
${ }^{3}$ These are short-run results. Therefore, all the analyses relate to the short run. The long-run analysis is based on Table 9.
} 
Table 2. Matrix of correlations

\begin{tabular}{|c|c|c|c|c|c|c|c|c|c|}
\hline Variables & (1) & (2) & (3) & (4) & (5) & (6) & (7) & (8) & (9) \\
\hline (1) DTE & 1.000 & & & & & & & & \\
\hline (2) BORROW & 0.008 & 1.000 & & & & & & & \\
\hline (3) IQUAL & -0.081 & 0.004 & 1.000 & & & & & & \\
\hline (4) $\mathrm{WOB}$ & 0.019 & -0.055 & -0.077 & 1.000 & & & & & \\
\hline (5) GROWTH & 0.044 & 0.071 & 0.046 & -0.033 & 1.000 & & & & \\
\hline (6) FIN.DEV & 0.004 & 0.086 & 0.422 & -0.119 & 0.180 & 1.000 & & & \\
\hline (7) PROFIT & -0.029 & 0.075 & 0.020 & -0.043 & 0.054 & 0.060 & 1.000 & & \\
\hline (8) SIZE & 0.012 & 0.660 & -0.021 & 0.021 & 0.022 & 0.036 & 0.095 & 1.000 & \\
\hline (9) EFFICl & -0.060 & -0.069 & 0.152 & -0.038 & -0.372 & -0.193 & -0.049 & 0.024 & 1.000 \\
\hline
\end{tabular}

DTE, debt to equity ratio; BORROW, borrowings; IQUAL, institutional quality; WOB, women on boards; PROFIT, profitability; SIZE, size of an MFI; EFFICI, efficiency of an MFI. 
Table 3. Baseline results: effect of institutional quality on the capital structure of MFIs

\begin{tabular}{|c|c|c|c|c|}
\hline & (1) & (2) & (3) & (4) \\
\hline Variables & Debt to equity ratio & Borrowings & Debt to equity ratio & Borrowings \\
\hline \multirow[t]{2}{*}{ Debt to equity $(-1)$} & $0.117^{\star \star}$ & & $0.135^{\star}$ & \\
\hline & $(0.055)$ & & $(0.075)$ & \\
\hline \multirow[t]{2}{*}{ Borrowings (log) $(-1)$} & & 0.338 & & 0.165 \\
\hline & & $(0.216)$ & & $(0.166)$ \\
\hline \multirow[t]{2}{*}{ Institutional quality } & $-1.863^{\star \star \star}$ & $-0.678^{\star \star \star}$ & $-1.587^{\star \star}$ & $-0.261^{\star}$ \\
\hline & $(0.588)$ & $(0.242)$ & $(0.774)$ & $(0.157)$ \\
\hline \multirow[t]{2}{*}{ Women on boards (log) } & 0.834 & $-0.300^{\star \star}$ & 0.682 & $-0.270^{\star \star \star}$ \\
\hline & $(0.627)$ & $(0.131)$ & $(0.684)$ & $(0.095)$ \\
\hline \multirow[t]{2}{*}{ Profitability } & & & $-3.538^{\star \star \star}$ & -0.036 \\
\hline & & & $(1.177)$ & $(0.259)$ \\
\hline \multirow[t]{2}{*}{ Size(log) } & & & $0.296^{*}$ & $0.586^{\star \star \star}$ \\
\hline & & & $(0.156)$ & $(0.152)$ \\
\hline \multirow[t]{2}{*}{ Efficiency (log) } & & & -0.584 & $-0.132^{\star \star}$ \\
\hline & & & $(0.362)$ & $(0.053)$ \\
\hline \multirow[t]{2}{*}{ Financial development } & & & 0.022 & 0.003 \\
\hline & & & $(0.022)$ & $(0.003)$ \\
\hline \multirow[t]{2}{*}{ Economic growth } & & & 0.146 & 0.033 \\
\hline & & & $(0.092)$ & $(0.025)$ \\
\hline \multirow[t]{2}{*}{ Constant } & $519.947^{\star *}$ & -85.719 & $516.040^{\star \star}$ & $108.497^{\star \star}$ \\
\hline & $(247.720)$ & $(79.290)$ & $(224.941)$ & $(48.732)$ \\
\hline Time dummies & Yes & Yes & Yes & Yes \\
\hline Instruments/MFIs & $11 / 438$ & $11 / 424$ & $16 / 425$ & $16 / 416$ \\
\hline F-statistic & 5.43 & 19.27 & 7.72 & 65.74 \\
\hline $\operatorname{AR}(2)$ ( $p$-value) & 0.088 & 0.195 & 0.083 & 0.289 \\
\hline Hansen test ( $p$-value) & 0.413 & 0.159 & 0.514 & 0.428 \\
\hline Observations & 847 & 812 & 816 & 789 \\
\hline GMM lag & 1 & 1 & 1 & 1 \\
\hline
\end{tabular}

Authors' computation. Standard errors in parentheses. ${ }^{* *} p<0.01,{ }^{* *} p<0.05,{ }^{*} p<0.1$.

Standard errors are robust to account for heteroskedasticity ${ }^{\star}$ and autocorrelation.

theory. It seems an improved institutional environment enables MFIs to operate more profitably. These profits, coupled with the subsidies some of them receive from donors and governments, allow them to finance their operations without relying much on borrowing.

Women are known to be more risk-averse than men. The results in Table 3 appear to confirm this. In columns 2 and 4, the coefficient of women on boards is negative and statistically significant. This suggests that an increase in the board gender diversity of an MFI leads to a drop in its utilization of debt. Holding other factors constant, an addition of one woman to the board of directors of an MFI causes about a $27-30 \%$ decrease in the capital structure of MFIs.

Profitability negatively loads on the debt-to-equity ratio. It suggests that as an MFI's profitability improves, this translates into less utilization of debt capital. This accords with pecking order theory. 
The coefficient of size is positive and statistically significant. A unit increase in the size of an MFI causes between 29.6 and $58.6 \%$ increase in its capital structure, ceteris paribus. Put more succinctly, an increase in the size of an MFI is associated with its use of more debt, holding other factors constant. This confirms our prediction and lends credence to the findings of Matemilola et al. (2019), Oino and Ukaegbu (2015), and Frank and Goyal (2009). Larger MFIs may have more tangible fixed assets which they can easily pledge as collateral to secure debt contracts. This makes such MFIs more predisposed to accessing more debt to finance their operations.

Our prediction of a positive relationship between efficiency and capital structure is unsupported. In column 4, the coefficient of efficiency is negative and statistically significant at the $5 \%$ significance level. A unit increase in the inefficiency ${ }^{4}$ (i.e. a US dollar increase in the cost per borrower) of an MFI results in the reduction in its debt utilization of about $13.2 \%$, ceteris paribus. This may be explained in terms of the reluctance of financial markets to support inefficient MFIs due to their higher risk.

Contrary to the study of Tchakoute Tchuigoua (2014), financial sector development has no significant impact on the capital structure of MFIs. We are, therefore, unable to confirm our prediction of a positive effect. Similarly, economic growth has no statistically significant impact on capital structure. This diverges from the growing number of studies that report that macroeconomic variables exert a substantial effect on the capital structure decisions of firms (Bancel and Mittoo, 2004; de Jong et al., 2008; Demirgüç-Kunt and Maksimovic, 1999; Fan et al., 2012; Namara et al. 2017; Tchakoute Tchuigoua, 2014).

\subsection{Additional results from the components of institutional quality}

In this section, we attempt to unravel the effect of each of the six public governance variables used to estimate institutional quality on the capital structure of MFIs. The results are reported in Table $4 .{ }^{5}$ In the table, the coefficients of control of corruption, the rule of law, regulatory quality, and voice and accountability are negative and statistically significant.

Holding other factors constant, a unit increase in the control of corruption causes 1.089 reduction in the capital structure of MFIs operating in that country. According to Hermes and Hudon (2018), an effective reduction in corruption implies decreasing the possibilities for small-scale businesses to circumvent all kinds of costly government rules and tax payments, which may make it more difficult for them to access government services that are difficult to obtain without paying bribes. This may negatively affect their operations and reduce their demand for the financial services offered by MFIs. This reduction in demand will in turn may reduce MFIs' debt capital.

A unit increase in the rule of law index of a country results in 1.018 reduction in the debt utilization of MFIs in that country, ceteris paribus. We explain this by the managerial fear hypothesis. In an environment where the rule of law prevails, creditor rights are more robust. Stronger creditor rights instill the fear of bankruptcy in managers which drive them to employ a less-than-optimal level of leverage or hold unnecessarily high levels of cash to prevent costly winding up of their firms (Acharya et al., 2011; Cho et al., 2014; Vig, 2013).

Regulatory quality does not support MFIs' debt utilization. It appears when the regulatory index of a country goes up by a unit, the capital structure of an MFI decreases by 1.903 , holding other factors constant. This outcome departs from the evidence in the empirical literature (Belkhir et al., 2016; Matemilola et al., 2019). More stringent policies and regulations produce constraints that hinder MFIs' access to debt capital; hence, the negative relationship between regulatory quality and capital structure.

Matemilola et al. (2019) report that voice and accountability has a positive effect on debt ratios.

\footnotetext{
${ }^{4}$ This is cost. Therefore, an increase represents inefficiency.

${ }^{5}$ We report only the debt-to-equity measure of capital structure results. Those of borrowings are not reported but are available upon a reasonable request.
} 
Table 4. Effects of components of institutional quality on capital structure of MFIs

\begin{tabular}{|c|c|c|c|c|c|c|}
\hline System GMM estimates & & & & & & \\
\hline & (1) & (2) & (3) & (4) & (5) & (6) \\
\hline Variables & DTE & DTE & DTE & DTE & DTE & DTE \\
\hline \multirow[t]{2}{*}{ Debt to equity $(-1)$} & $0.142^{\star \star}$ & $0.138^{*}$ & $0.141^{*}$ & $0.139^{\star}$ & $0.140^{*}$ & $0.131^{\star}$ \\
\hline & $(0.070)$ & $(0.073)$ & $(0.072)$ & $(0.080)$ & $(0.072)$ & $(0.075)$ \\
\hline \multirow[t]{2}{*}{ Women on boards(log) } & 0.740 & 0.707 & 0.671 & 0.747 & 0.683 & 0.794 \\
\hline & $(0.661)$ & $(0.694)$ & $(0.683)$ & $(0.690)$ & $(0.691)$ & $(0.696)$ \\
\hline \multirow[t]{2}{*}{ Profitability } & $-3.572^{\star \star \star}$ & $-3.468^{\star \star \star}$ & $-3.509^{\star \star \star}$ & $-2.907^{\star \star \star}$ & $-3.639^{\star \star \star}$ & $-3.635^{\star \star \star}$ \\
\hline & (1.099) & $(1.160)$ & $(1.161)$ & $(1.106)$ & $(1.140)$ & $(1.130)$ \\
\hline \multirow[t]{2}{*}{ Size(log) } & $0.356^{\star \star}$ & $0.315^{\star \star}$ & $0.326^{\star \star}$ & $0.290^{*}$ & $0.330^{\star \star}$ & $0.335^{\star *}$ \\
\hline & $(0.152)$ & $(0.153)$ & $(0.150)$ & $(0.165)$ & $(0.149)$ & $(0.152)$ \\
\hline \multirow[t]{2}{*}{ Efficiency(log) } & $-0.719^{\star \star}$ & $-0.645^{\star}$ & $-0.692^{\star}$ & -0.204 & $-0.733^{\star \star}$ & $-0.681^{\star \star}$ \\
\hline & $(0.364)$ & $(0.367)$ & $(0.353)$ & $(0.244)$ & $(0.343)$ & $(0.332)$ \\
\hline \multirow[t]{2}{*}{ Financial development } & 0.008 & 0.016 & 0.017 & 0.024 & 0.018 & 0.015 \\
\hline & $(0.020)$ & $(0.021)$ & $(0.020)$ & $(0.023)$ & $(0.020)$ & $(0.019)$ \\
\hline \multirow[t]{2}{*}{ Economic growth } & 0.132 & 0.139 & $0.143^{*}$ & $0.145^{*}$ & 0.138 & 0.124 \\
\hline & $(0.088)$ & $(0.090)$ & $(0.086)$ & $(0.082)$ & $(0.087)$ & $(0.084)$ \\
\hline \multirow[t]{2}{*}{ Political stability } & 0.064 & & & & & \\
\hline & $(0.512)$ & & & & & \\
\hline \multirow[t]{2}{*}{ Control of corruption } & & $-1.089^{\star}$ & & & & \\
\hline & & $(0.598)$ & & & & \\
\hline \multirow[t]{2}{*}{ The rule of law } & & & $-1.018^{\star}$ & & & \\
\hline & & & $(0.572)$ & & & \\
\hline \multirow[t]{2}{*}{ Regulatory quality } & & & & $-1.903^{\star \star}$ & & \\
\hline & & & & $(0.769)$ & & \\
\hline
\end{tabular}


Table 4. (Continued.)

\begin{tabular}{|c|c|c|c|c|c|c|}
\hline System GMM estimates & & & & & & \\
\hline & (1) & (2) & (3) & (4) & (5) & (6) \\
\hline Variables & DTE & DTE & DTE & DTE & DTE & DTE \\
\hline \multirow[t]{2}{*}{ Government effectiveness } & & & & & -1.018 & \\
\hline & & & & & $(0.734)$ & \\
\hline \multirow[t]{2}{*}{ Voice and accountability } & & & & & & $-0.842^{\star}$ \\
\hline & & & & & & $(0.454)$ \\
\hline \multirow[t]{2}{*}{ Constant } & $503.974^{\star \star}$ & $518.620^{\star *}$ & $491.125^{\star \star}$ & $539.591^{\star \star}$ & $534.400^{\star *}$ & $536.300^{\star \star \star}$ \\
\hline & (215.989) & $(233.520)$ & $(217.500)$ & $(238.684)$ & $(213.118)$ & (199.908) \\
\hline Time dummies & Yes & Yes & Yes & Yes & Yes & Yes \\
\hline Instruments & $16 / 425$ & $16 / 425$ & $16 / 425$ & $16 / 425$ & $16 / 425$ & $16 / 425$ \\
\hline F-statistic & 7.94 & 7.48 & 9.25 & 9.45 & 7.98 & 7.65 \\
\hline $\operatorname{AR}(2)$ & 0.081 & 0.084 & 0.079 & 0.077 & 0.078 & 0.076 \\
\hline Hansen test & 0.561 & 0.515 & 0.521 & 0.515 & 0.523 & 0.549 \\
\hline Observations & 816 & 816 & 816 & 816 & 816 & 816 \\
\hline GMM lag & 1 & 1 & 1 & 1 & 1 & 1 \\
\hline
\end{tabular}

DTE, the debt-to-equity ratio.

Source: Authors' computation. Standard errors in parentheses. ${ }^{* * *} p<0.01,{ }^{* *} p<0.05,{ }^{*} p<0.1$

Standard errors are robust to account for heteroskedasticity and autocorrelation. 
Evidence in both Table 4 contradicts this. In the table, a unit increase in the voice and accountability causes 0.842 reduction in capital structure, holding other factors constant.

\subsection{Moderating role of women on boards in institutional quality-capital structure link}

To answer the question of whether women on boards play any significant role in the institutional quality-capital structure nexus, we estimate another dynamic regression in which women on boards variable interacts with institutional quality index and its significant components. We report only the results of the debt-to-equity ratio measure of capital structure. The results of borrowings as a measure of capital structure are not reported but are available upon a reasonable request.

The results show that the coefficient of institutional quality index when interacts with women on boards is $-13.363(-18.923+5.560)$. It implies that the interaction does not change its negative effect on capital structure. It rather deepens the magnitude. Among the components of institutional quality, it is only voice and accountability that exhibits a higher negative effect on capital structure when it interacts with women on boards. In all, holding other factors constant, the presence of more women on the board of an MFI is likely to significantly reduce the likelihood of the MFI accessing debt from capital markets. Thus, women on boards play a moderating role in the institutional quality-capital structure nexus (Table 5).

\subsection{Robustness check}

The baseline model is converted into a static model and estimated by the pooled and random effects regression techniques. We display the results ${ }^{6}$ in Table 6. Columns 1 and 2 present the results from the pooled regression technique, whereas columns 3 and 4 show the results from the random effects regression. The coefficient of institutional quality is negative across the four columns except that in columns 2 and 4, it is statistically insignificant. Generally, these results uphold those reported in Table 3.

Table 5. Moderating role of women on boards in the institutional quality-capital structure link

\begin{tabular}{|c|c|c|c|c|c|}
\hline \multicolumn{6}{|l|}{ System GMM estimates } \\
\hline & $(1)$ & (2) & (3) & (4) & (5) \\
\hline Variables & DTE & DTE & DTE & DTE & DTE \\
\hline \multirow{2}{*}{ Debt to equity $(-1)$} & $0.125^{\star}$ & $0.123^{*}$ & $0.136^{\star}$ & $0.129^{*}$ & $0.145^{\star}$ \\
\hline & $(0.073)$ & $(0.072)$ & $(0.070)$ & $(0.076)$ & $(0.074)$ \\
\hline \multirow[t]{2}{*}{ Institutional quality } & $5.560^{\star *}$ & & & & \\
\hline & $(2.706)$ & & & & \\
\hline \multirow[t]{2}{*}{ Women on boards $(\%)^{7}$} & $-4.778^{\star \star}$ & -2.135 & 6.054 & -0.432 & $4.178^{\star \star}$ \\
\hline & $(2.264)$ & $(4.072)$ & $(4.943)$ & $(0.656)$ & $(1.708)$ \\
\hline \multirow[t]{2}{*}{ IQWOB } & $-18.923^{\star \star}$ & & & & \\
\hline & $(7.397)$ & & & & \\
\hline \multirow[t]{2}{*}{ Profitability } & $-3.359^{\star \star \star}$ & $-3.161^{\star \star}$ & $-2.753^{\star \star}$ & $-2.904^{\star \star \star}$ & $-2.977^{\star \star}$ \\
\hline & $(1.271)$ & $(1.287)$ & $(1.242)$ & $(1.110)$ & $(1.151)$ \\
\hline
\end{tabular}

\footnotetext{
${ }^{6}$ The choice between fixed effects and random effects regression technique is made based on the Hausman test result.

${ }^{7}$ We use percent of females on boards.
} 
Table 5. (Continued.)

\begin{tabular}{|c|c|c|c|c|c|}
\hline \multicolumn{6}{|l|}{ System GMM estimates } \\
\hline & (1) & $(2)$ & (3) & (4) & (5) \\
\hline Variables & DTE & DTE & DTE & DTE & DTE \\
\hline \multirow[t]{2}{*}{ Size } & $0.281^{\star}$ & 0.288 & $0.304^{\star}$ & $0.354^{\star *}$ & $0.318^{\star \star}$ \\
\hline & $(0.155)$ & $(0.190)$ & $(0.159)$ & $(0.164)$ & $(0.150)$ \\
\hline \multirow[t]{2}{*}{ Efficiency } & -0.594 & -0.601 & -0.651 & -0.536 & -0.562 \\
\hline & $(0.484)$ & $(0.558)$ & $(0.447)$ & $(0.331)$ & $(0.396)$ \\
\hline \multirow[t]{2}{*}{ Financial development } & 0.037 & 0.031 & 0.024 & 0.034 & 0.029 \\
\hline & $(0.027)$ & $(0.028)$ & $(0.020)$ & $(0.025)$ & $(0.020)$ \\
\hline \multirow[t]{2}{*}{ Economic growth } & $0.169^{\star}$ & 0.176 & $0.194^{\star \star}$ & $0.211^{\star *}$ & $0.177^{\star \star}$ \\
\hline & $(0.098)$ & $(0.110)$ & $(0.085)$ & $(0.085)$ & $(0.081)$ \\
\hline \multirow[t]{2}{*}{ Control of corruption } & & 2.311 & & & \\
\hline & & $(4.006)$ & & & \\
\hline \multirow[t]{2}{*}{ CORRUPWOB } & & -9.492 & & & \\
\hline & & $(12.266)$ & & & \\
\hline \multirow[t]{2}{*}{ The rule of law } & & & -1.803 & & \\
\hline & & & (1.181) & & \\
\hline \multirow[t]{2}{*}{ ROLWOB } & & & 1.396 & & \\
\hline & & & $(1.834)$ & & \\
\hline \multirow[t]{2}{*}{ Regulatory quality } & & & & 3.067 & \\
\hline & & & & (2.023) & \\
\hline \multirow[t]{2}{*}{ RQUALWOB } & & & & $-11.136^{\star \star \star}$ & \\
\hline & & & & $(4.180)$ & \\
\hline \multirow[t]{2}{*}{ Voice and accountability } & & & & & $3.333^{*}$ \\
\hline & & & & & $(1.854)$ \\
\hline \multirow[t]{2}{*}{ VACCWOB } & & & & & $-12.293^{\star \star}$ \\
\hline & & & & & $(5.521)$ \\
\hline \multirow[t]{2}{*}{ Constant } & 122.040 & 280.696 & 292.728 & 215.183 & 31.301 \\
\hline & (319.299) & $(380.892)$ & $(256.453)$ & $(277.682)$ & $(313.770)$ \\
\hline Time dummies & Yes & Yes & Yes & Yes & Yes \\
\hline Instruments & $17 / 397$ & $17 / 397$ & $17 / 397$ & $17 / 397$ & $17 / 397$ \\
\hline F-statistic & 6.92 & 5.49 & 7.47 & 7.94 & 6.79 \\
\hline $\operatorname{AR}(2)$ & 0.118 & 0.148 & 0.158 & 0.139 & 0.142 \\
\hline Hansen test & 0.345 & 0.266 & 0.396 & 0.525 & 0.610 \\
\hline Observations & 756 & 756 & 756 & 756 & 756 \\
\hline
\end{tabular}

IQWOB; CORRUPWOB; ROLWOB; RQWOB; and VACCWOB are the interaction between women on boards and regulatory quality, control of corruption, the rule of law, regulatory quality and voice and accountability respectively. Standard errors in parentheses.

${ }^{\star \star \star} p<0.01,{ }^{\star \star} p<0.05,{ }^{\star} p<0.1$. Standard errors are robust to account for heteroskedasticity and autocorrelation. 
Table 6. Robustness checks

\begin{tabular}{|c|c|c|c|c|}
\hline \multicolumn{5}{|c|}{ Pooled results random effects results } \\
\hline & (1) & (2) & (3) & (4) \\
\hline Variables & DTE & Borrowings & DTE & Borrowings \\
\hline \multirow[t]{2}{*}{ Institutional quality } & $-4.048^{\star \star \star}$ & -0.131 & $-4.055^{\star \star \star}$ & -0.101 \\
\hline & $(1.026)$ & $(0.111)$ & $(1.048)$ & $(0.142)$ \\
\hline \multirow[t]{2}{*}{ Women on boards(log) } & -0.108 & $-0.343^{\star \star \star}$ & -0.091 & $-0.362^{\star \star \star}$ \\
\hline & $(0.540)$ & $(0.058)$ & $(0.553)$ & $(0.075)$ \\
\hline \multirow[t]{2}{*}{ Profitability } & -1.227 & -0.156 & -1.156 & -0.058 \\
\hline & $(1.001)$ & $(0.108)$ & $(1.011)$ & $(0.117)$ \\
\hline \multirow[t]{2}{*}{ Size(log) } & -0.011 & $0.778^{\star \star \star}$ & -0.014 & $0.752^{\star \star \star}$ \\
\hline & $(0.196)$ & $(0.021)$ & $(0.200)$ & $(0.027)$ \\
\hline \multirow[t]{2}{*}{ Efficiency(log) } & -0.029 & $-0.151^{\star \star \star}$ & -0.032 & $-0.157^{\star \star \star}$ \\
\hline & $(0.297)$ & $(0.032)$ & $(0.302)$ & $(0.040)$ \\
\hline \multirow[t]{2}{*}{ Financial development } & $0.062^{\star \star \star}$ & $0.006^{\star \star}$ & $0.062^{\star \star \star}$ & $0.007^{\star \star}$ \\
\hline & $(0.021)$ & $(0.002)$ & $(0.022)$ & $(0.003)$ \\
\hline \multirow[t]{2}{*}{ Economic growth } & $0.258^{\star}$ & $0.029^{\star \star}$ & $0.252^{\star}$ & 0.021 \\
\hline & $(0.133)$ & $(0.014)$ & $(0.134)$ & $(0.015)$ \\
\hline \multirow[t]{2}{*}{ Constant } & 19.244 & $72.582^{\star \star}$ & 10.194 & $74.337^{\star \star}$ \\
\hline & (329.245) & $(35.503)$ & (331.142) & $(36.044)$ \\
\hline Time dummies & Yes & Yes & Yes & Yes \\
\hline Observations & 1,515 & 1,469 & 1,515 & 1,469 \\
\hline$R^{2}$ & 0.018 & 0.522 & 0.017 & 0.521 \\
\hline Wald $\chi^{2}$ & - & - & $26.01^{\star \star \star}$ & $924.67^{\star \star \star}$ \\
\hline No. of MFIs & - & - & 532 & 527 \\
\hline
\end{tabular}

Baseline model estimated by pooled and random effects regression techniques.

Source: Authors' computation. Standard errors in parentheses. ${ }^{* \star *} p<0.01,{ }^{* \star} p<0.05,{ }^{*} p<0.1$

\subsection{Long-run effects of institutional quality on capital structure}

Finally, the results of the analysis of the long-run effect of institutional quality on capital structure are presented in Table 7. Also, the long-run effects of the components of institutional quality that have demonstrated statistically significant short-run effects on capital structure as well as the long-run effects of the significant control variables in the baseline model are presented in Table 7. Institutional quality has maintained its adverse short-run effects on capital structure in the long-run except that under borrowings, its coefficient is statistically insignificant. All the components of institutional quality have also maintained their short-run effects on capital structure in the long run. Generally, these results underpin the postulation that institutional quality attenuates the propensity of MFIs to seek debt financing in the long term. Other variables (profitability, size, and women on boards) have all kept their short-run effects on capital structure in the long run.

\section{Conclusion}

This paper interrogates the issue of whether institutional quality drives the capital structure of MFIs. Apart from interrogating the effect of the composite institutional quality index on capital structure, we 
Table 7. Long-run relationship between institutional quality and capital structure

\begin{tabular}{|c|c|c|}
\hline \multirow[b]{2}{*}{ Variables } & \multicolumn{2}{|c|}{ Capital structure measures } \\
\hline & Debt-to-equity ratio & Borrowings(log) \\
\hline Institutional quality & $\begin{array}{l}-1.835^{\star \star} \\
(-2.08)\end{array}$ & $\begin{array}{l}-0.313 \\
(-1.57)\end{array}$ \\
\hline Control of corruption & $\begin{array}{l}-1.263^{*} \\
(-1.82)\end{array}$ & $\begin{array}{l}-0.310 \\
(-1.59)\end{array}$ \\
\hline Rule of law & $\begin{array}{l}-1.186^{\star} \\
(-1.80)\end{array}$ & - \\
\hline Regulatory quality & $\begin{array}{c}-1.211^{\star \star \star} \\
(-2.57)\end{array}$ & - \\
\hline Voice and accountability & $\begin{array}{l}-0.969^{\star} \\
(-1.87)\end{array}$ & $\begin{array}{l}-0.245^{\star} \\
(-1.82)\end{array}$ \\
\hline Profitability & $\begin{array}{c}-4.089^{\star \star \star} \\
(-3.17)\end{array}$ & \\
\hline Size & $\begin{array}{l}0.342^{\star \star} \\
(1.98)\end{array}$ & $\begin{array}{c}0.702^{\star \star \star} \\
(12.68)\end{array}$ \\
\hline Women on boards & & $\begin{array}{c}-0.323^{\star \star \star} \\
(-3.18)\end{array}$ \\
\hline Efficiency & & $\begin{array}{c}-0.158^{\star \star \star} \\
(-2.76)\end{array}$ \\
\hline
\end{tabular}

Source: Authors' computations. Z-statistics are in parentheses. ${ }^{\star \star \star} p<0.01,{ }^{\star \star} p<0.05,{ }^{\star} p<0.1$.

Standard errors are robust to account for heteroskedasticity and autocorrelation.

also emulate the study of Matemilola et al. (2019) to disentangle the effect of each of the six governance variables in the index on capital structure. Furthermore, we ask whether the presence of women on the boards of MFIs moderates the link between institutional quality and capital structure.

In line with pecking order theory, we observe a negative and statistically significant effect of institutional quality on the capital structure of MFIs in both the short and long run. In the short term, the robustness of this adverse effect is tested by the use of different estimation techniques. Among the six governance variables, control of corruption, the rule of law, regulatory quality, and voice and accountability come up as slowing down the capital structure of MFIs in both the short and long run. Collectively, these results support the conclusion that an improvement in the institutional environment of MFIs attenuates their propensity to access debt funding from financial markets. Our moderation analysis reveals that the presence of women on the board of an MFI decreases MFIs' tendency to seek debt financing.

One implication of our results is that an improvement in institutional quality may not promote microfinancing through borrowed funds. This emphasizes the uniqueness of the business model of MFIs. Another implication is that MFIs may reduce their leverage levels so as to decrease their exposure to bankruptcy risk by ensuring more female representation on their boards.

Does institutional quality slow down the capital structure of MFIs because it improves their financial performance in such a way that they become operationally self-sufficient to deflect the need for external financing? We have not been able to answer this question. Future research is, therefore, needed in this direction.

The sample used in this study may not be representative of the global microfinance industry. This is because the MIX platform hosts data from MFIs that have voluntarily disclosed them. Notwithstanding this concern, we believe the study has policy relevance given the limited research on the capital structure of MFIs and the fact that the determinants of the capital structure of privately held firms remain an important and unresolved issue in the finance literature (Cole, 2013). 


\section{References}

Acharya, V. V., Y. Amihud and I. Litov (2011), 'Creditor Rights and Corporate Risk-Taking', Journal of Financial Economics, 102: $150-166$.

Adams, R. B. and D. Ferreira (2009), 'Women in the Boardroom and Their Impact on Governance and Performance', Journal of Financial Economics, 94(2): 291-309.

Adusei, M. and Y. T. Obeng (2019), 'Board Gender Diversity and the Capital Structure of Microfinance Institutions', The Quarterly Review of Economics and Finance, 71: 258-269.

Afrifa, G. A., E. Gyapong and A. M. Zalata (2019), 'Buffer Capital, Loan Portfolio Quality and Performance of Microfinance Institutions: A Global Analysis', Journal of Financial Stability, 44: 100691.

Ahlin, C., J. Lin and M. Maio (2011), 'Where Does Microfinance Flourish? Microfinance Institution Performance in Macroeconomic Context', Journal of Development Economics, 95: 105-120.

Alves, P., E. B. Couto and P. M. Francisco (2015), "Board of Directors' Composition and Capital Structure", Research in International Business and Finance, 35: 1-32.

Amihud, Y. and B. Lev (1981), 'Risk Reduction as a Managerial Motive for Conglomerate Mergers', Bell Journal of Economics, 12(2): 605-617.

Arellano, M. and S. Bond (1991), 'Some Tests of Specification for Panel Data: Monte Carlo Evidence and an Application to Employment', Review of Economic Studies, 58: 277-297.

Arellano, M. and O. Bover (1995), 'Another Look at the Instrumental Variable Estimation of Error Components Models', Journal of Econometrics, 68(1): 29-51.

Awartani, B., M. Belkhir, S. Boubaker and A. Maghyereh (2016), 'Corporate Debt Maturity in the MENA Region: Does Institutional Quality Matter?', International Review of Financial Analysis, 46: 309-325.

Bancel, F. and U. R. Mittoo (2004), 'Cross-country Determinants of Capital Structure Choice: A Survey of European Firms', Financial Management, 33(4): 103-132.

Barometer, M. (2019), Available at: http://www.convergences.org.

Beck, T., A. Demirgüç-Kunt and V. Maksimovic (2008), 'Financing Patterns Around the World: Are Small Firms Different?', Journal of Financial Economics, 89(3): 467-487.

Belkhir, M., A. Maghyereh and B. Awartani (2016), 'Institutions and Corporate Capital Structure in the MENA Region', Emerging Markets Review, 26: 99-129.

Bibi, U., H. O. Balli, C. D. Matthews and D. W. L. Tripe (2018), 'New Approaches to Measure the Social Performance of Microfinance Institutions (MFIs)', International Review of Economics and Finance, 53: 88-97.

Blundell, R. and S. R. Bond (1998), 'Initial Conditions and Moment Restrictions in Dynamic Panel Data Models', Journal of Econometrics, 87: 115-144.

Booth, L., V. Aivazian, A. DemirgucKunt and V. Maksimovic (2001), 'Capital Structure in Developing Countries', Journal of Finance, 56: 87-130.

Byrnes, J., D. Miller and W. Schafer (1999), 'Gender Differences in Risk-Taking: A Meta-analysis', Psychological Bulletin, 125: 367-383.

Chen, N. (2011), 'Securities Laws, Control of Corruption, and Corporate Liquidity: International Evidence', Corporate Governance: An International Review, 19(1): 3-24.

Cho, S.-S., S. El Ghoul, O. Guedhami and J. Suh (2014), 'Creditor Rights and Capital Structure: Evidence from International Data', Journal of Corporate Finance, 25: 40-60.

Cole, R. A. (2013), 'What Do We Know About the Capital Structure of Privately Held US Firms? Evidence From the Surveys of Small Business Finance', Journal of Financial Management, 42(4): 777-813.

Daskalakis, N., D. Balios and V. Dalla (2017), 'The Behavior of SMEs' Capital Structure Determinants in Different Macroeconomic States', Journal of Corporate Finance, 46: 248-260.

De Jong, A., R. Kabir and T. T. Nguyen (2008), 'The Capital Structure Around the World: The Roles of Firm-and Country-Specific Determinants', Journal of Banking and Finance, 32: 1954-1969.

Demirgüç-Kunt, A. and V. Maksimovic (1999), 'Institutions, Financial Markets, and Firm Debt Maturity', Journal of Financial Economics, 54: 295-336.

Demirgüç-Kunt, A., M. S. M. Peria and T. Tressel (2020), 'The Global Financial Crisis and the Capital Structure of Firms: Was the Impact More Severe among SMEs and Non-Listed Firms?', Journal of Corporate Finance, 60: 101514.

D’Espallier, B., M. Hudon and A. Szafarz (2013), 'Unsubsidized Microfinance Institutions', Economic Letters, 120: $174-176$.

DiMaggio, P. J. and W. W. Powell (1983), 'The Iron Cage Revisited: Institutional Isomorphism and Collective Rationality in Organizational Fields', American Sociological Review, 48(2): 147-160.

Djankov, S., C. McLiesh and A. Shleifer (2007), 'Private Credit in 129 Countries', Journal of Financial Economics, 84: 299 -329.

Donaldson, G. (1961), Corporate Debt Capacity, Boston, MA: Harvard University Press.

Dorfleitner, G., E. Oswald and M. Röhea (2019), 'The Access of Microfinance Institutions to Financing via the Worldwide Crowd', The Quarterly Review of Economics and Finance, https://doi.org/10.1016/j.qref.2019.03.010

Dortfleitner, G., M. Röhe and N. Renier (2017), 'The Access of Microfinance Institutions to Debt Capital: An Empirical Investigation of Microfinance Investment Vehicles', The Quarterly Review of Economics and Finance, 65: 1-15. 
Du, J. (2008), 'Corruption and corporate finance patterns: an international perspective', Pacific Economic Review, 13(2): 183208.

Earne, J. and J. Sherk (2013), 'Funding', in J. Ledgerwood, J. Earne and C. Nelson (eds.), The new Microfinance Handbook: A Financial Market System Perspective. Washington, DC: The World Bank, pp. 379-412.

Fan, P. H., S. Titman and T. Twite (2012), 'An International Comparison of Capital Structure and Debt Maturity Choices', Journal of Financial and Quantitative Analysis, 47: 23-46.

Fernando, N. A. (2004), Micro Success Story? Transformation of Nongovernment Organizations Into Regulated financial Institutions, Mandaluyong City, Philippines: Asian Development Bank.

Frank, M. Z. and V. K. Goyal (2009), 'Capital Structure Decisions: Which Factors Are Reliably Important?', Financial Management, 38: 1-37.

Friend, I. and L. H. Lang (1988), 'An Empirical Test of the Impact of Managerial Self-Interest on Corporate Capital Structure', Journal of Finance, 43(2): 271-281.

Garmaise, M. J. and G. Natividad (2010), 'Information, the Cost of Credit, and Operational Efficiency: An Empirical Study of Microfinance', Review of Financial Studies, 23(6): 2561-2590.

Haselman, R., K. Pistor and V. Vig (2010), 'How the Law Affects Lending', Review of Financial Studies, 23(2): 549-580.

Hermes, N. and M. Hudon (2018), 'Determinants of the Performance of Microfinance Institutions: Systematic Review', Journal of Economic Surveys, 32(5): 1483-1151.

Jensen, M. C. (1986), 'Agency Costs of Free Cash Flow, Corporate Finance and Takeovers', American Economic Review, 76(2): 323-329.

Kaufmann, D., A. Kraay and M. Mastruzzi (2010), The Worldwide Governance Indicators: A Summary of the Methodology, Data, and Analytical Issues. World Bank Policy Research Working Paper No. 5430.

Kieschnicka, R. and R. Moussawi (2018), 'Firm Age, Corporate Governance, and Capital Structure Choices', Journal of Corporate Finance, 48: 597-614.

La Porta, R., F. Lopez-de-Silanes, A. Shleifer and W. R. Vishny (1997), 'Legal Determinants of External Finance', Journal of Finance, 52: 1131-1150.

Ledgerwood, J. and V. White (2006), Transforming Microfinance Institutions: Providing Full financial Services to the Poor, Washington, DC: The World Bank.

Lemma, T. T. (2014), 'Corruption, Debt Financing, and Corporate Ownership', Journal of Economic Studies, 42(3): 433-461.

Li, D. and M. P. Ferreira (2011), 'Institutional Environment and Firms' Sources of Financial Capital in Central and Eastern Europe', Journal of Business Research, 64: 371-376.

Matemilola, B. T., A. N. Bany-Ariffin, W. N. W. Azman-Saini and M. N. Annuar (2019), 'Impact of Institutional Quality on the Capital Structure of Firms in Developing Countries', Emerging Markets Review, 39: 175-209.

Mersland, R. and L. Urgeghe (2013), 'International Debt Financing and Performance of Microfinance Institutions', Strategic Change, 22(1-2): 17-29.

Morduch, J. (1999), 'The Microfinance Promise', Journal of Economic Literature, 37(4): 1569-1614.

Myers, S. C. (1984), 'The Capital Structure Puzzle', Journal of Finance, 32: 575-592.

Namara, A. M., P. Murro and S. O’Donohoe (2017), 'Countries Lending Infrastructure and Capital Structure Determination: The Case of European SMEs', Journal of Corporate Finance, 43: 122-138.

Oino, I. and B. Ukaegbu (2015), 'The Impact of Profitability on Capital Structure and Speed of Adjustment: An Empirical Examination of Selected Firms in the Nigeria Stock Exchange, Research in International Business and Finance, 35: $111-121$.

öztekin, ö. and M. J. Flannery (2012), 'Institutional Determinants of Capital Structure Adjustment Speeds', Journal of Financial Economics, 103: 88-112.

Psillaki, M. and N. Daskalakis (2009), 'Are the Determinants of Capital Structure Country or Firm-Specific?', Small Business Economics, 33(3): 319-333.

Reed, L. (2015), State of the Microcredit Summit Campaign Report 2, Washington, DC: Microcredit Summit.

Rose-Ackerman, S. (2006), International Handbook on the Economics of Corruption, Washington, DC: Edward Elgar Publishing.

Selznick, P. (1957), Leadership and Administration, New York: HarperCollins.

Shah, A., H. A. Shah, J. M. Smith and G. J. Labianca (2017), 'Judicial Efficiency and Capital Structure: An International Study', Journal of Corporate Finance, 44: 255-274.

Shleifer, A. and R. Vishny (1993), 'Corruption', Quarterly Journal of Economics, 108(3): 599-617.

Sila, V., A. Gonzalez and J. Hagendorff (2016), 'Women on Board: Does Boardroom Gender Diversity Affect Firm Risk?', Journal of Corporate Finance, 36: 26-53.

Strøm, R. Ø., B. D’Espallier and R. Mersland (2014), 'Female leadership, performance, and governance in microfinance institutions', Journal of Banking and Finance, 42: 60-75.

Stulz, R. M. (2005), 'The Limits of Financial Globalization', The Journal of Finance, 60(4): 1595-1638.

Tanzi, V. (1998), 'Corruption around the world: causes, consequences, scope, and cures', IMF Staff Papers, 45(4): 559-594.

Tchakoute Tchuigoua, H. (2014), 'Institutional Framework and Capital Structure of Microfinance Institutions', Journal of Business Research. http://dx.doi.org/10.1016/j.jbusres.2014.01.008 
Tchakoute Tchuigoua, H. (2016), 'Buffer Capital in Microfinance Institutions', Journal of Business Research, 69: $3523-3537$. Touil, M. and C. Mamoghli (2019), 'Institutional Environment and Determinants of Adjustment Speed to the Target Capital Structure in the MENA Region,' Borsa Istanbul Review, https://doi.org/10.1016/j.bir.2019.12.003

Vig, V. (2013), 'Access to Collateral and Corporate Debt Structure: Evidence From A Natural Experiment', Journal of Finance, 68: 881-928. www.convergences.org/wp-content/uploads/2019/09/Microfinance-Barometer-2019_web-1.pdf.

\section{Appendix A}

MFIs selected from each MFI region

\begin{tabular}{llrr}
\hline No. & \multicolumn{1}{c}{ Region } & MFIs & \% of sample \\
\hline 1 & Africa & 29 & 5 \\
\hline 2 & East Asia and the Pacific & 42 & 8 \\
\hline 3 & Eastern Europe and Central Asia & 83 & 16 \\
\hline 4 & Latin America and The Caribbean & 214 & 40 \\
\hline 5 & Middle East and North Africa & 8 & 2 \\
\hline 6 & South Asia & 156 & 29 \\
\hline & Total & 532 & 100 \\
\hline
\end{tabular}

Cite this article: Adusei M, Sarpong-Danquah B (2021). Institutional quality and the capital structure of microfinance institutions: the moderating role of board gender diversity. Journal of Institutional Economics 17, 641-661. https://doi.org/ $10.1017 /$ S1744137421000023 